\title{
Optimal planting density for cut Lilium and tuberose production
}

\author{
Iftikhar Ahmad ${ }^{1 *}$, Waqas Hussain Naeem ${ }^{1}$ and Bilal Abdullah
}

\begin{abstract}
Lilium and tuberose are promising geophytic flowers, which have high market demand in global floral markets. A study was conducted to optimize planting densities for cut lilium and tuberose production. Bulbs of Asiatic lily 'Brunello' and tuberose 'Single' were planted on $7.5 \mathrm{~cm}, 15.0 \mathrm{~cm}$ and $22.5 \mathrm{~cm}$ between bulbs while ridge were spaced at $60 \mathrm{~cm}$ apart. Lilium bulbs planted at 22.5 $\mathrm{cm}$ took $185 \mathrm{~d}$, while tuberose took $101 \mathrm{~d}$ to produce flowers as compared to $7.5 \mathrm{~cm}$ spacing ( $173 \mathrm{~d}$ and $93 \mathrm{~d}$, respectively). Bulbs of lilium and tuberose planted at $22.5 \mathrm{~cm}$ resulted in tallest plants with highest leaf area for both tested species, $69.1 \mathrm{~cm}$ and 11.4 $\mathrm{cm}^{2}$ for lilium and $110.6 \mathrm{~cm}$ and $30.2 \mathrm{~cm}^{2}$ for tuberose, respectively. Both species had highest number of florets with longer stem/ spike length and stem/spike diameter when planted $22.5 \mathrm{~cm}$ apart, while close planting further decrease number of buds/florets and stem/spike length. Similar results were recorded for fresh weight of a stem, while vase life and dry weight of a stem were relatively less affected by plant spacing. However, lilium and tuberose bulbs when planted at $22.5 \mathrm{~cm}$ plant spacing produced higher number of best quality stems for market as compared to other planting densities.
\end{abstract}

Keywords: Cut flowers, geophytes, plant spacing, vase life

\section{Introduction}

Lilium L. hybrids and Polianthes tuberosa L. (tuberose) members of family Liliaceae and Amaryllidaceae, respectively, are major bulbous crops which are being grown as cut flowers all over the world (Huang et al., 2001; Saifullah et al., 2010). Lilium is one of the leading cut flowers all over the world, which ranks $7^{\text {th }}$ among cut flowers in the world in terms of auction turnover. It is cultivated on an area of 5,172 ha with Netherlands leading with 4,280 ha (Buschman, 2005). There has been a big market demand for exotic cultivars of Lilium in Pakistan due to their majestic long slender perfumed and showy flowers, and these are being imported in ever increasing quantities. Pakistani areas with cool temperate winter have the potential for commercial cultivation of this fabulous exotic plant on large scale to diversify and improve local cut flower industry. Similarly, tuberose is the only bulbous cut flower which is available during hot summer months and is a hardy bulbous cut flower (Ahmad et al., 2009; Asif et al., 2016).

Plants require proper space to grow and to uptake available essentials like water, nutrition, air and light. Plant density plays significant role in plants growth and development. Close plant spacing resulted in less growth by limited uptake of nutrients and water from soil, so planting distance should be proper for seeds and corms to get higher quality stems (Mane et al., 2007; Amjad and Ahmad, 2012). Therefore, yield and quality of cut stems depends on number of plants per square meter and dependent on cultivar/species (Inaba and Ohshiro, 2004). In developed countries, lilium is being produced in hi-tech greenhouses using plastic crates, however, in many developing countries, soil cultivation is being practiced, which needs information about optimal planting density for uniform plant growth and best quality cut stem production.

Lilium is emerging bulbous cut flower whose market demand is rising in Pakistan while tuberose is only bulbous flower available in Pakistan market during summer. However, their optimal planting density has not been determined for field production. Therefore, a study was conducted to optimize plant spacing for quality cut stem production of Lilium L. hybrids and Polianthes tuberosa L.

\section{Materials and methods}

Bulbs of Asiatic lily 'Brunello' and tuberose 'Single' were planted on $7.5 \mathrm{~cm}, 15.0 \mathrm{~cm}$ and $22.5 \mathrm{~cm}$ between bulbs, while ridges were spaced at $60 \mathrm{~cm}$. Lilium bulbs were planted on $15^{\text {th }}$ October, 2015, while tuberose bulbs on $15^{\text {th }}$ April, 2016, comprising total study period of one

${ }^{1}$ University of Agriculture, Institute of Horticultural Sciences, Faisalabad- 38040, Pakistan *Corresponding author's: iftikharahmadhashmi@gmail.com, iahmad@uaf.edu.pk

Received Octobe, 12, 2018 | Accepted May 21, 2019

Licensed by CC BY 4.0

http://dx.doi.org/10.14295/oh.v25i2.1736 
year (Figure 1). Before planting, bulbs were treated with fungicide $2 \mathrm{~g} \mathrm{~L}^{-1}$ (Ridomil Gold; Metalaxyl-M and Sisomer) solution for $10 \mathrm{~min}$. and dried under shade. Soil was thoroughly prepared, enriched with basal fertil- izer [NPK (20:20:20)] at $100 \mathrm{~kg}$ per acre and laid out. Experiments were laid out for each crop according to randomized complete block design (RCBD) with three replications.
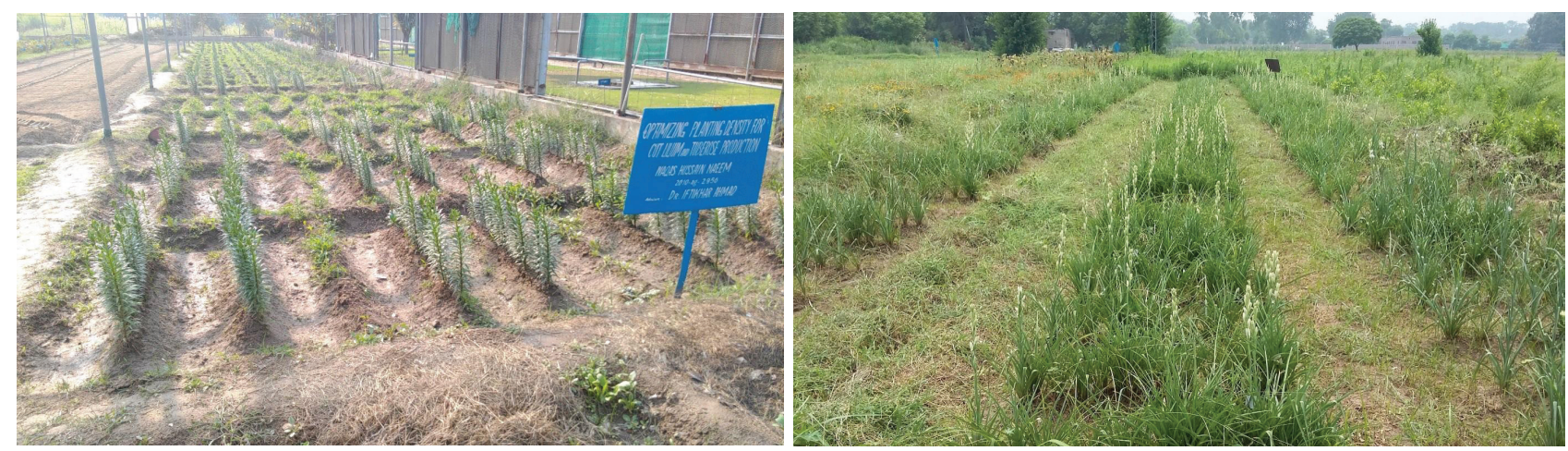

Figure 1. Lilium (A) and tuberose (B) plantings planted at various planting densities.

Data regarding plant growth parameters were collected using standard procedures. Plant height was recorded using meter rod, while leaf area was measured in $\mathrm{cm}^{2}$ of fully matured leaves according to Carleton and Foote (1965) using formula (length $\times$ breath $\times 0.68)$. Leaf total chlorophyll contents (SPAD) were measured using leaf chlorophyll meter (Minolta spad-502) after 60 days of planting bulbs. Stem or spike diameter ( $\mathrm{mm}$ ) and buds/ florets/flower diameter $(\mathrm{mm})$ were measured with digital vernier caliper (Model; 0604CAL8). Lilium stems were harvested when first bud started to open, while tuberose spikes were harvested when 4-5 florets were open. Stem /spike quality were rated on scale from 1 to 9 (( 1 $=$ poor quality and $9=$ best quality) according to Cooper and Spokas (1991) For vase life (d) evaluation, stems were recut to uniform length 50 and $60 \mathrm{~cm}$ for lilium and tuberose, respectively) and placed individually in jars containing $250 \mathrm{~mL}$ distilled water until termination and considered terminated when $>50 \%$ of the florets/petals exhibited termination symptoms. Stem fresh weight (g) was recorded after harvest, while dry weight (g) was recorded after placing stems in an oven at $70^{\circ} \mathrm{C}$ for 72 hours.
All other cultural practices like integrated pest management, fertilization, weeding, earthing up, staking, etc. were similar for all the treatments during entire study period. Data were analyzed using analysis of variance (ANOVA) using Statistix (version 8.1) and treatment means were compared according to LSD at 5\% level of probability (Steel et al., 1997).

\section{Results}

\section{Lilium}

Lilium bulbs planted at $22.5 \mathrm{~cm}$ took more time (185 d) to produce flowers as compared to those planted at $7.5 \mathrm{~cm}$ (173 d) (Table 1). Bulbs spaced at $22.5 \mathrm{~cm}$ produced tallest plants $(69.1 \mathrm{~cm})$ with greatest leaf area $\left(11.4 \mathrm{~cm}^{2}\right)$ and highest leaf total chlorophyll contents (70.1 SPAD) (Table $1)$. Moreover, tallest stem length $(43.7 \mathrm{~cm})$ and stem diameter $(7.7 \mathrm{~mm})$ with greatest number of florets (5.4) was recorded for bulbs planted at in the $22.5 \mathrm{~cm}$ plant spacing (Table 1). Similarly, highest stem fresh weight (84.4 g) and dry weight (13.9 g) was observed at wider bulb spacing $(22.5 \mathrm{~cm})$. However, flower diameter and vase life were not affected by plant spacing (Table 1). 
Table 1. Effect of planting densities (PD) on production time (PT) (days from planting to harvest), plant height (PH) (cm), leaf area (LA) $\left(\mathrm{cm}^{2}\right)$, leaf total chlorophyll contents (LTCC) (SPAD), stem length (SL) (cm), stem diameter (SD) (mm), buds per stem (BS) (no.), flower diameter (FD) (cm), stem fresh weight (SFW) (g), stem dry weight (SDW) (g), flower quality (FQ) (1-9), and vase life (VL) (d) of cut lilium 'Brunello'. All data represent means of 15 plants.

\begin{tabular}{|c|c|c|c|c|c|c|c|c|c|c|c|c|}
\hline $\begin{array}{l}\text { PD } \\
(\mathrm{cm})\end{array}$ & $\begin{array}{l}\text { PT } \\
\text { (d) }\end{array}$ & $\begin{array}{l}\text { PH } \\
(\mathrm{cm})\end{array}$ & $\begin{array}{c}\text { LA } \\
\left(\mathrm{cm}^{2}\right)\end{array}$ & $\begin{array}{c}\text { LTCC } \\
\text { (SPAD) }\end{array}$ & $\begin{array}{c}\text { SL } \\
(\mathrm{cm})\end{array}$ & $\begin{array}{c}\text { SD } \\
(\mathrm{mm})\end{array}$ & $\begin{array}{c}\text { BS } \\
\text { (no.) }\end{array}$ & $\begin{array}{c}\text { FD } \\
(\mathrm{cm})\end{array}$ & $\begin{array}{c}\text { SFW } \\
\text { (g) }\end{array}$ & $\begin{array}{l}\text { SDW } \\
\text { (g) }\end{array}$ & $\begin{array}{l}F^{z} \\
(1-9)\end{array}$ & $\begin{array}{l}\text { VL } \\
\text { (d) }\end{array}$ \\
\hline 7.5 & $173 \mathrm{c}^{\mathrm{y}}$ & $53.8 \mathrm{c}$ & $4.3 \mathrm{~b}$ & $28.4 \mathrm{c}$ & $38.3 \mathrm{~b}$ & $5.5 \mathrm{c}$ & $3.8 \mathrm{c}$ & 23.5 & $57.7 \mathrm{~b}$ & $11.9 \mathrm{~b}$ & $5.0 \mathrm{~b}$ & 11.8 \\
\hline 15.0 & $180 \mathrm{~b}$ & $62.1 \mathrm{~b}$ & $6.1 \mathrm{~b}$ & $50.5 \mathrm{~b}$ & $41.6 \mathrm{a}$ & $6.7 \mathrm{~b}$ & $4.8 \mathrm{~b}$ & 22.2 & $72.4 \mathrm{a}$ & $12.3 \mathrm{~b}$ & $7.0 \mathrm{~b}$ & 11.9 \\
\hline 22.5 & $185 \mathrm{a}$ & $69.1 \mathrm{a}$ & $11.4 \mathrm{a}$ & $70.1 \mathrm{a}$ & $43.7 \mathrm{a}$ & $7.7 \mathrm{a}$ & $5.4 \mathrm{a}$ & 23.53 & $84.4 \mathrm{a}$ & $13.9 \mathrm{a}$ & $8.4 \mathrm{a}$ & 12.0 \\
\hline Significance $^{\mathrm{x}}$ & 0.0047 & 0.0040 & 0.0013 & 0.0002 & 0.0074 & $<0.0001$ & 0.0006 & NS & 0.0013 & 0.0298 & 0.0362 & NS \\
\hline
\end{tabular}

${ }^{\mathrm{z}}$ Stem overall quality rating from 1 to $9(1=$ poor quality, $9=$ best quality).

${ }^{y}$ Means followed by the same letter are not significantly different according to least significant difference test at $\mathrm{P} \leq 0.05$.

xProbability values were obtained using the General Linear Models (GLM) procedure of Statistix (version 8.1) for significant effect of planting densities. NS = not significant at $\mathrm{P}>0.05$.

\section{Tuberose}

Tuberose bulbs produced earliest (93 d) spikes when planted at $7.5 \mathrm{~cm}$, while took $101 \mathrm{~d}$ to produce flowers when planted at $22.5 \mathrm{~cm}$ spacing (Table 2). Tallest plants $(110.6 \mathrm{~cm})$ with greater leaf area $\left(30.2 \mathrm{~cm}^{2}\right)$ and leaf total chlorophyll contents (75.8 SPAD) were produced when spaced at $22.5 \mathrm{~cm}$ (Table 2). Tuberose bulbs spaced at 7.5 $\mathrm{cm}$ produced shortest stem length $(88.3 \mathrm{~cm})$ with least stem diameter $(4.8 \mathrm{~mm})$, floret diameter $(30.4 \mathrm{~mm})$ and less florets number per stem (29.5) (Table 2). Greatest stem fresh weight $(38.4 \mathrm{~g})$ and dry weight $(8.7 \mathrm{~g})$ was recorded in bulbs spaced at $22.5 \mathrm{~cm}$. Similarly, wider plant spacing $(22.5 \mathrm{~cm})$ produced best stem/flower quality $(8.8)$ and longest vase life (12.3 d) (Table 2).

Table 2. Effect of planting densities (PD) on production time (PT) (days from planting to harvest), plant height (PH) (cm), leaf area (LA) $\left(\mathrm{cm}^{2}\right)$, leaf total chlorophyll contents (LTCC) (SPAD), stem length (SL) (cm), stem diameter (SD) (mm), florets per stem (FS) (no.), flower diameter (FD) (mm), stem fresh weight (SFW) (g), stem dry weight (SDW) (g), flower quality (FQ) (1-9) and vase life (VL) (days) of tuberose 'Single'. All data represent means of 15 plants.

\begin{tabular}{|c|c|c|c|c|c|c|c|c|c|c|c|c|}
\hline $\begin{array}{l}\text { PD } \\
(\mathrm{cm})\end{array}$ & $\begin{array}{l}\text { PT } \\
\text { (d) }\end{array}$ & $\begin{array}{l}\text { PH } \\
(\mathrm{cm})\end{array}$ & $\begin{array}{c}\text { LA } \\
\left(\mathrm{cm}^{2}\right)\end{array}$ & $\begin{array}{c}\text { LTCC } \\
\text { (SPAD) }\end{array}$ & $\begin{array}{c}\text { SL } \\
(\mathrm{cm})\end{array}$ & $\begin{array}{c}\text { SD } \\
(\mathrm{mm})\end{array}$ & $\begin{array}{c}\text { FS } \\
\text { (no.) }\end{array}$ & $\begin{array}{c}\text { FD } \\
(\mathrm{mm})\end{array}$ & $\begin{array}{c}\text { SFW } \\
\text { (g) }\end{array}$ & $\begin{array}{c}\text { SDW } \\
\text { (g) }\end{array}$ & $\begin{array}{l}F^{z} \\
(1-9)\end{array}$ & $\begin{array}{l}\text { VL } \\
\text { (d) }\end{array}$ \\
\hline 7.5 & $93.5 \mathrm{c}^{\mathrm{y}}$ & $90.3 \mathrm{c}$ & $23.5 \mathrm{~b}$ & $44.5 \mathrm{a}$ & $88.3 \mathrm{~b}$ & $4.8 \mathrm{c}$ & $29.5 \mathrm{~b}$ & $30.4 \mathrm{~b}$ & $26.0 \mathrm{~b}$ & $6.0 \mathrm{ab}$ & $7.0 \mathrm{~b}$ & $8.3 \mathrm{c}$ \\
\hline 15.0 & $96.7 \mathrm{~b}$ & $101 \mathrm{~b}$ & $24.7 \mathrm{~b}$ & $64.8 \mathrm{ab}$ & 98.7 a & $7.1 \mathrm{~b}$ & $38.8 \mathrm{a}$ & $35.9 \mathrm{a}$ & $34.1 \mathrm{a}$ & $7.1 \mathrm{~b}$ & $8.4 \mathrm{a}$ & $10.3 \mathrm{~b}$ \\
\hline 22.5 & $101.3 \mathrm{a}$ & $110.6 \mathrm{a}$ & $30.2 \mathrm{a}$ & $75.8 \mathrm{a}$ & $101.6 \mathrm{a}$ & $8.5 \mathrm{a}$ & $41.0 \mathrm{a}$ & $37.7 \mathrm{a}$ & $38.4 \mathrm{a}$ & $8.7 \mathrm{a}$ & $8.8 \mathrm{a}$ & $12.3 \mathrm{a}$ \\
\hline Significance ${ }^{x}$ & $<0.0001$ & 0.0003 & 0.0005 & 0.036 & 0.003 & 0.002 & 0.004 & 0.036 & 0.008 & 0.091 & 0.022 & 0.002 \\
\hline
\end{tabular}

${ }^{z}$ Stem overall quality rating from 1 to $9(1=$ poor quality, $9=$ best quality).

${ }^{\mathrm{y}}$ Means followed by the same letter are not significantly different according to least significant difference test at $\mathrm{P} \leq 0.05$.

xProbability values were obtained using the General Linear Models (GLM) procedure of Statistix (version 8.1) for significant effect of planting densi-

\section{Discussion}

Plant growth depends on availability of nutrition and plant population per unit area which ultimately affects flowers yield and quality. Study was conducted on a loamy soil with pH (8.7), EC (2.5 dS m $\left.{ }^{-1}\right)$, organic matter $(0.66 \%)$, nitrogen contents $(6.5 \%)$, phosphorous contents $(9.7 \mathrm{mg}$ $\mathrm{kg}^{-1}$ ) and potassium contents (203 $\left.\mathrm{mg} \mathrm{kg}^{-1}\right)$. Both species produced tallest plants with grater leaf area and leaf total chlorophyll contents when spaced at wider spacing, which may be due to more nutrients uptake from soil through root hairs and more available space and consequent more photosynthetic production (Tehranifar and Akbari, 2012). Similarly, greatest leaf area and chlorophyll contents re- 
sulted higher photosynthesis rate for lilium bulbs planted at wider spacing (Amjad and Ahmad, 2012). Results contradicts with the findings of Singh and Sangama (2001) who reported tallest plant height with deeper planting and closer spacing of gladiolus. Lilium and tuberose bulbs planted at wider spacing $(22.5 \mathrm{~cm})$ produced greatest stems length, diameter with greater flowers/florets per stem, which may be due to less nutrient competition among plants and availability of sunlight (Tehranifar and Akbari, 2012). Similarly, Kawarkhe et al. (2001) reported that number of spikes per plant and spike length increased with the increase in application rates of $\mathrm{P}$ fertilizers in gladiolus. However, Mishra et al. (2002) recorded higher number of florets per stems in higher planting density. Tuberose had more florets per stem compared to lilium, which might be due to the genetic differences, growth habit and their potential on various agroclimatic conditions (Blaine, 1999; Balaram et al., 2009). Stem fresh and dry weight was increased when bulbs of both species were planted at wider spacing, which might be due higher nutrition uptake (Kazaz et al., 2011). Similarly, flower quality was best when spaced at higher plant spacing, which may be due to higher sunlight availability and air circulation among plants.

\section{Conclusion}

Lilium and tuberose bulbs planted at $22.5 \mathrm{~cm}$ plant spacing produced better quality stems as compared to those planted at $7.5 \mathrm{~cm}$ and $15.0 \mathrm{~cm}$ spacing, however, for early production, close spacing may be adopted.

\section{Author Contribution}

I.A. ${ }^{0000-0002-6427-2123}$ : Planned and supervised the research experiments and reviewed the manuscript, W.H.N. ${ }^{0000-0002-7221-4089}$ : Performed the experiment and collected data, B.A. ${ }^{0000-0001-5910-5040 .}$ Analyzed data and wrote the first draft of manuscript.

\section{Acknowledgements}

Authors are grateful to 'Higher Education Commission of Pakistan (HEC)' for partial financial support for the study through NRPU project No. 4946 and 3435.

\section{References}

AHMAD, I.; AHMAD, T.; ASIF, M.; SALEEM, M.; AKRAM, A. Effect of bulb size on growth, flowering and bulbils production of tuberose. Sarhad Journal of Agriculture, v.25, n.3, p.391-397, 2009.

AMJAD, A.; AHMAD, I. Optimizing plant density, planting depth and postharvest preservatives for Lilium longifolium. Journal of Horticultural Science \& Ornamental Plants, v.2, n.1, p.13-20, 2012.

ASIF, M.; AHMAD, I.; QASIM, M.; BASHIR, M. Vase water quality impact postharvest performance of cut tuberose (Polianthes tuberosa L.) 'Single' spikes. Pakistan Journal of Agricultural Sciences, v. 53, n.4, p.925-931, 2016.
BALARAM, M.V.; JANAKIRAM, T.; VASANTHA, K.E. Performance of Indian and exotic gladiolus genotypes. Journal of Ornamental Horticulture, v.12, n.2, p.95-100, 2009.

BLAINE, A.C. Selection and production of six herbaceous flowering perennial species as greenhouse grown alternative cut flowers. M. Sc. Thesis. Dept. Hort. Land. Architec. Colorado State University, Colorado, 1999.

BUSCHMAN, J.C.M. Globalization-flowers-flower bulbsbulb flowers. Acta Horticulturae, v.673, p.27-33, 2005.

CARLETON, M.; FOOTE, K.A. Comparison of methods for estimating total leaf area of barley plants. Crop Science, v.5, n.6, p.602-603, 1965.

COOPER, R.J.; SPOKAS, L.A. Growth, quality and foliar iron concentration of Kentucky Blue Grass treated with chelated iron source. Journal of the American Society for Horticultural Science, v.116, n.5, p.798-801, 1991. DOI: https://doi.org/10.21273/JASHS.116.5.798

HUANG, K.L.; MIYAJIMA, I.; OKUBO, H.; SHEN, T.M.; HUANG, T.S. Breeding of colored tuberose (Polianthes tuberosa L.) and cultural experiments in Taiwan. Acta Horticulturae, v.570, p.367-371, 2001.

INABA, Z.; OHSHIRO, M. Effects of the nursing seedling method and winter night temperature on flowering, yields and quality of snapdragons (Antirrhinum majus L.). Horticultural Research Japan, v.3, n.3, p.273-276, 2004. DOI: https://doi.org/10.2503/hrj.3.273

INABA, Z.; KATO, C.; HORIUCHI, M.; OHTSUKA. $\mathrm{H}$. Effect of planting density, container size and period of raising seedlings on the flowering and quality of snapdragon cut flowers in non-pinching culture. Horticultural Research Japan, v.9, n.2, p.165-170, 2010. DOI: https:// doi.org/10.2503/hrj.9.165

KAWARKHE, V.J.; JANE, R.N.; JADHAO, B.J. Effect of nitrogen and phosphorus fertilization on growth and flowering in gladiolus variety Dabonoir. The Orissa Journal of Horticulture, v.29, n.2, p.31-34, 2001.

KAZAZ, S.; TEKINTAS, F.E.; ASKIN, M.A. Effects of different planting systems and densities on yield and quality in standard carnations. Journal of Cell \& Plant Science, v.2, n.1, p.19-23, 2011a.

KAZAZ, S.; TEKINTA, F.E.; ASKIN, M.A. Effects of planting density and system on growth and flowering of spray carnations. Journal of Cell \& Plant Science, v.2, n.2, p.1-6, 2011 b.

MANE, P.K.; BANKAR, G.J.; MAKNE, S.S. Influence of spacing, bulb size and depth of planting on flower yield and quality of tuberose (Polianthes tuberosa L.) cv. Single. Indian Journal of Agricultural Research, v.41, n.1, p.71-74, 2007. 
MISHRA, M.; MOHAPATRA, A.; MOHANTY, C.R. Effect of N, P and spacing on tuberose. Floriculture research trend in India. Proceedings of the national symposium on Indian floriculture in the new millennium, Lal-Bagh, Bangalore. p. 338-339, 2002.

SAIFULLAH, K.; SHEEBA, N.; MARIAM, R.; NAHEED, K.; ASMA, N.; BUSHRA, S. Cultivation of lilies (Lilium regale) for commercialization in Pakistan. Pakistan Journal of Botany, v.42, n.2, p.1103-1113, 2010.

SINGH, K.; SANGAMA, P. Effect of planting densities on growth, flowering and postharvest quality of cut spike in tuberose (Polianthes tuberosa) cv. 'Single'. Journal of Applied Horticulture, v.2, n.1, p.54-55, 2001.
STEEL, R.G.D.; TORRIE, J.H.; DICKEY, D.A. Principles and Procedures of Statistics: A Biometrical Approach, $3^{\text {rd }}$ ed. McGraw-Hill Book Co., New York, 1997.

TEHRANIFAR, A.; AKBARI, R. Effect of Planting Depth, Bulb Size and Their Interactions on Growth and Flowering of Tuberose (Polianthes tuberosa L.). American-Eurasian Journal of Agricultural \& Environmental Sciences, v.12, n.11, p.1452-1456, 2012. 